\title{
Remarks on Heat Emission during Operation in Hot Rock Mass and on Possibilities of Its Use
}

\author{
Janusz Cygankiewicz ${ }^{1} \&$ Józef Knechtel ${ }^{1}$ \\ ${ }^{1}$ Central Mining Institute, Department of Mining Aerology, Katowice, Poland \\ Corespondence: Józef Knechtel, Central Mining Institute, Department of Mining Aerology, 40-166 Katowice Plac \\ Gwarków 1, Poland. Tel: (32)259-21-94, fax: (32) 259-21-94. E-mail: jknechtel@gig.katowice.pl
}

Received: October 2, 2014

Accepted: October 17, 2014

Online Published: February 20, 2015

doi:10.5539/jgg.v7n1p46

URL: http://dx.doi.org/10.5539/jgg.v7n1p46

\begin{abstract}
Heat flow in a hot mining department, where the original temperature of rock is greater than $50^{\circ} \mathrm{C}$ has been studied. The total power of electrical equipment installed in the department amounts to about $6 \mathrm{MW}$. In accordance with the current climate regulations of Polish mining, the air temperature in the workplace, measured with a dry-bulb thermometer may not be higher than $33^{\circ} \mathrm{C}$. In order to be able to ensure a temperature consistent with the regulations in such department, fresh air supply workings must be equipped with chillers of a total refrigeration capacity of $2 \mathrm{MW}$. The carried out analysis of the results of climate forecasts and of the results of the rock mass cooling modelling around these workings has shown that approximately $30 \%$ of the cooling power is needed to receive the heat from the hot rock massif. Assuming the required air temperature at $28^{\circ} \mathrm{C}$ (enabling an unshortened working time), then the cooling power needed to extract heat from the rock mass would be much greater. The studies carried out show that the amount of heat emitted in the department also depends on the phase of the longwall course (the length of main gates and changes in rock temperature in them). It has been proposed that hot water from condensers supplies the crystallizers of surface (absorption) cooling devices. In this way, reduction of the air-conditioning expenditure will be obtained.
\end{abstract}

Keywords: hot rock mass, heat transfer, heat recovery

\section{Introduction}

Currently, in coal mines of the Upper Silesian Coal Basin and in adjacent Czech OKD mines, operation is carried out in rock mass of the original temperature well above $40^{\circ} \mathrm{C}$, and in the mines of OKD even over $50^{\circ} \mathrm{C}$. Taking into account the additional heat sources from technological processes, whose total power amount from 4 to $6 \mathrm{MW}$, and more, it is necessary to install a cooling system with a power of app. 2 MW for the air-conditioning of the operation area. A question may arise whether it is possible to use even a part of the energy expended on the work of the cooling equipment. Works (Knechtel, 2006) show that the direct use of heat contained in the mine air through its removal on the surface is scarcely realistic, because the air is significantly cooled before it reaches the surface. Instead, the possibility of transferring this heat with hot water powering the cooling devices may be considered.

\section{Cooling Power Needed in a Hot Mining Department}

The active OKD mine operation region consisting of inclines (length of $830 \mathrm{~m}$ ), bottom road (length of $700 \mathrm{~m}$ ), extraction longwall (length of $150 \mathrm{~m}$ ) and of top road (length of $620 \mathrm{~m}$ ) is considered. This area is located at a depth of -860 to $-980 \mathrm{~m}$ (fig. 1). The original temperature of rocks in the incline amounts from 50.9 to $53.4^{0} \mathrm{C}$, in the bottom road from 53.4 to $50.1^{\circ} \mathrm{C}$, in the longwall and bottom road from 49.5 to $52.8^{0} \mathrm{C}$. The extraction from the longwall amounts to $4000 \mathrm{t} / \mathrm{d}$. Total power of technological equipment in the fresh air flow is as follows: in the incline $-1595 \mathrm{~kW}$, in the bottom road $2520 \mathrm{~kW}$ and in the longwall $2315 \mathrm{~kW}$. Large cross-section of roadways (19.2 $\left.\mathrm{m}^{2}\right)$ and of longwall $\left(12.2 \mathrm{~m}^{2}\right)$ enables a very large intensity of the area ventilation $\left(30 \mathrm{~m}^{3} / \mathrm{s}=1800 \mathrm{~m}^{3} / \mathrm{min}\right)$. The temperature of the fresh air flowing into the area is $26.3^{\circ} \mathrm{C}$ and its relative humidity amounts to app. $54 \%$. For the determination of the cooling power demand, 7 alternative climate forecasts have been performed:

- for the maximum longwall face (the maximum length of main gates),

- longwall face 100 metres shorter than the maximum face,

- longwall face 200 metres shorter than the maximum face, 
- longwall face 300 metres shorter than the maximum face,

- longwall face 400 metres shorter than the maximum face,

- longwall face 500 metres shorter than the maximum face,

- longwall face 600 metres shorter than the maximum face.

Table 1 summarizes the initial data for the climate forecasts for the maximum longwall face. The following are shown in specific columns of the table: working name, the cross-section surface - A, air outflow - V, index determining the part of working being uncovered by coal $-\mathrm{k}$, geodetic heights of the sections of air inlets into the working $-\mathrm{z}_{\mathrm{d}}$ and its outlet $-\mathrm{z}_{\mathrm{w}}$, working length $-\mathrm{L}$, original temperature of rocks $-\mathrm{t}_{\mathrm{pg}}$, working ventilation time $\tau$, energy-mechanic device power - $\mathrm{N}$, weight of transported output $\mathrm{m}_{\mathrm{w}}$.

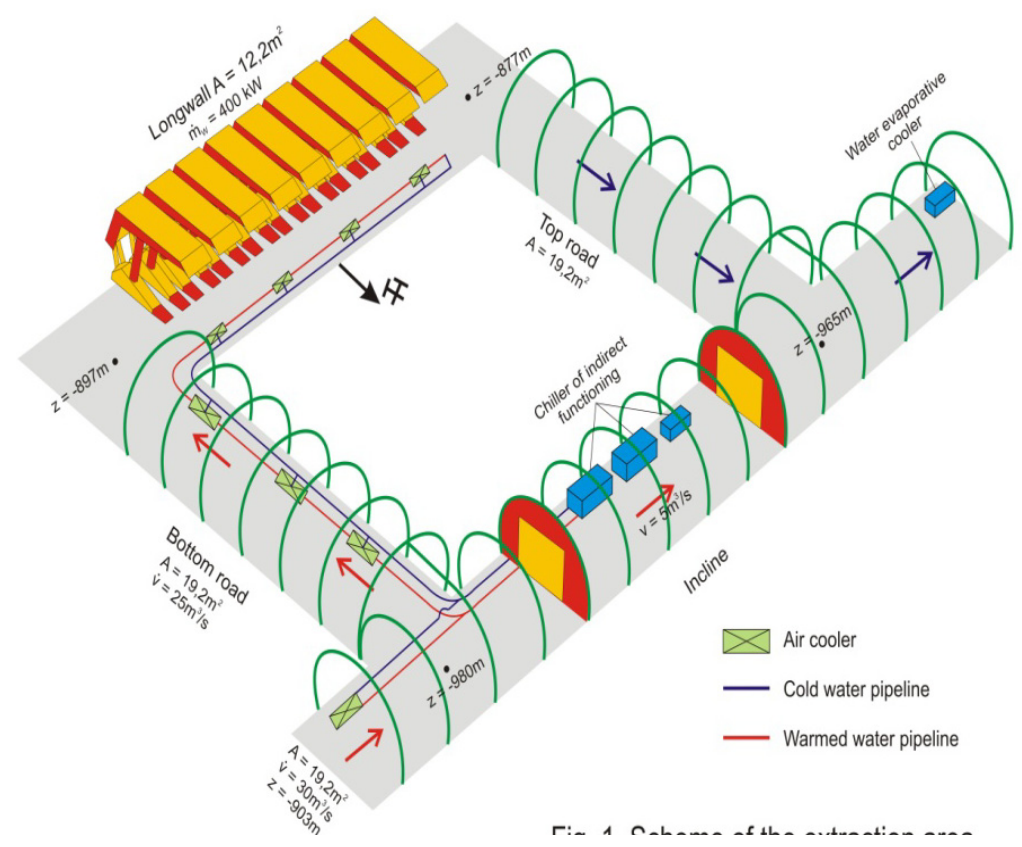

Figure 1. Scheme of the extraction area

Table 1. Initial data for the calculation of prognostic microclimate parameters of mine air in the area of longwall 40 in the "D" Mine - the maximum longwall face

\begin{tabular}{clcccccccccc}
\hline Branch & \multicolumn{1}{c}{$\begin{array}{c}\text { Branch name } \\
\text { (workings) }\end{array}$} & $\begin{array}{c}\mathrm{A} \\
\mathrm{m}^{2}\end{array}$ & $\begin{array}{c}\mathrm{V} \\
\mathrm{m}^{3} / \mathrm{min}\end{array}$ & $\mathrm{k}$ & $\begin{array}{c}\mathrm{z}_{\mathrm{d}} \\
\mathrm{m}\end{array}$ & $\begin{array}{c}\mathrm{Z}_{\mathrm{w}} \\
\mathrm{m}\end{array}$ & $\begin{array}{c}\mathrm{L} \\
\mathrm{m}\end{array}$ & $\begin{array}{c}\mathrm{t}_{\mathrm{pg}} \\
{ }^{\circ} \mathrm{C}\end{array}$ & $\begin{array}{c}\tau \\
\text { days }\end{array}$ & $\begin{array}{c}\mathrm{N} \\
\mathrm{kW}\end{array}$ & $\begin{array}{c}\mathrm{m}_{\mathrm{W}} \\
\mathrm{t} / \mathrm{d}\end{array}$ \\
\hline 1 & 19.2 & 1800 & 0.56 & -903.0 & -940.1 & 400 & 50.9 & 420 & 1063 & 4000 \\
2 & Incline 38 & 19.2 & 1800 & 0.56 & -940.1 & -980.0 & 430 & 52.1 & 300 & 532 & 4000 \\
3 & Bottom road 39 & 19.2 & 1500 & 0.56 & -980.0 & -930.0 & 350 & 53.4 & 120 & 1463 & 4000 \\
4 & Bottom road 39 (continued) & 19.2 & 1500 & 0.56 & -930.0 & -880.0 & 350 & 51.8 & 80 & 1057 & 4000 \\
5 & Longwall 40 & 12.2 & 1500 & 0.50 & -880.0 & -876.0 & 30 & 50.1 & 0.25 & 763 & 4000 \\
6 & Longwall 40 (continued) & 12.2 & 1350 & 0.50 & -876.0 & -872.0 & 30 & 49.9 & 0.25 & 263 & 3200 \\
7 & Longwall 40 (continued) & 12.2 & 1200 & 0.50 & -872.0 & -868.0 & 30 & 49.8 & 0.25 & 263 & 2400 \\
8 & Longwall 40 (continued) & 12.2 & 1200 & 0.50 & -868.0 & -864.0 & 30 & 49.6 & 0.25 & 263 & 1600 \\
9 & Longwall 40 (continued) & 12.2 & 1350 & 0.50 & -864.0 & -860.0 & 30 & 49.5 & 0.25 & 763 & 800 \\
10 & Top road 41 & 19.2 & 1500 & 0.56 & -860.0 & -965.0 & 620 & 49.5 & 180 & - & - \\
\hline
\end{tabular}

Parameters of the air in the section of the supply to the sequence of workings: $\mathrm{t}_{\mathrm{d}}=26.3^{0}(\mathrm{C}) ; \mathrm{t}_{\varphi \mathrm{d}}=19.8^{0} \mathrm{C} ; \varphi_{\mathrm{d}}=$ $53.77 \% ; X_{d}=0.01037$.

Climate forecasts assuming the lack of air-conditioning have been performed in the first place. In this case, the projected air temperature is very high. During the first days after the longwall movement, the temperature in the bottom road is much higher than $40^{\circ} \mathrm{C}$, and in the extraction longwall even higher than $49^{\circ} \mathrm{C}$. Along with the longwall coal-face advancement, this temperature drops to about $40^{\circ} \mathrm{C}$ in the section of the air inlet to the longwall 
and to close to $47^{\circ} \mathrm{C}$ in the section of the air outlet from the longwall. It is therefore necessary to cool the air along the fresh air course and along the longwall coal-face. It has been accepted that the cooling potential is to be chosen in such a way so that the air temperature measured with dry-bulb thermometer is not higher than $33^{\circ} \mathrm{C}$ anywhere in the air course. Calculations using the method described in work (Holek, 1990) have been performed. The author of the method described in the work (Holek, 1990) based, among others, on the results of researches carried out by Batzel (Batzel, 1952), Benet and Jouana (Benet \& Jouanna, 1982, 1983), Boldizsar (Boldizsar, 1960), Marzilger and Wagener (Marzilger \& Wagener, 1972), Nottrot and Sadeeg (Nottrot \& Sadeeg, 1966) as well as Voß (Voß, 1965, 1969).

The results of the climate forecasts for maximum longwall face - variant with the use of air-conditioning has been shown in table 2. The following have been presented in the table in the specific columns: distance coordinate calculated from the beginning of the incline $40920 \mathrm{~T} 19$ - x, air temperature measured with thermometers: dry-bulb - $t$ and wet-bulb $-t_{\varphi}$, relative humidity - $\varphi$, the degree of air humidity level - X. Moreover, these tables present the location and cooling power of the chillers. From the analysis of the results contained in this table and the results of the climate forecasts made for the remaining phases of the longwall course, it can be concluded that the cooling power needed in individual phases of the

longwall course is:

- for the maximum longwall face $-1895 \mathrm{~kW}$,

- longwall face 100 metres shorter than the maximum face - $1790 \mathrm{~kW}$,

- longwall face 200 metres shorter than the maximum face - $1605 \mathrm{~kW}$,

- longwall face 300 metres shorter than the maximum face - $1535 \mathrm{~kW}$,

- longwall face 400 metres shorter than the maximum face - $1425 \mathrm{~kW}$,

- longwall face 500 metres shorter than the maximum face - $1335 \mathrm{~kW}$,

- longwall face 600 metres shorter than the maximum face - $1175 \mathrm{~kW}$.

Assuming the advancement of the longwall coal-face equal to $100 \mathrm{~m} / \mathrm{month}$, it can be calculated that the amount of heat energy received by chillers from the air in the period of longwall movement is almost $28 \mathrm{TJ}$ (27 $889920 \mathrm{MJ})$.

Table 2. The results of the climate forecast for the workings in the area of longwall 40 in "D" Mine the maximum longwall face, variant including the cooling

\begin{tabular}{|c|c|c|c|c|}
\hline \multirow[t]{2}{*}{ Distance coordinate } & \multicolumn{2}{|c|}{ Air temperature measured with a thermometer } & \multirow[t]{2}{*}{ Relative air humidity } & \multirow[t]{2}{*}{ Air humidity degree } \\
\hline & dry-bulb & wet-bulb & & \\
\hline $\mathrm{x}, \mathrm{m}$ & $\mathrm{t},{ }^{0} \mathrm{C}$ & $\mathrm{t}_{\varphi,}{ }^{0} \mathrm{C}$ & $\varphi, \%$ & $\mathrm{X}$ \\
\hline 0 & 26.30 & 19.80 & 53.77 & 0.01037 \\
\hline 400 & 32.54 & 23.81 & 44.43 & 0.01201 \\
\hline $400 *$ & 25.32 & 20.95 & 72.22 & 0.01186 \\
\hline 830 & 32.12 & 25.35 & 55.84 & 0.01473 \\
\hline $830^{*}$ & 25.51 & 22.13 & 77.92 & 0.01347 \\
\hline 1180 & 32.26 & 26.17 & 60.18 & 0.01614 \\
\hline $1180^{*}$ & 26.08 & 23.04 & 80.09 & 0.01463 \\
\hline 1530 & 33.08 & 26.92 & 60.48 & 0.01713 \\
\hline $1530^{*}$ & 26.99 & 23.91 & 80.24 & 0.01560 \\
\hline 1560 & 29.31 & 25.71 & 74.26 & 0.01695 \\
\hline 1590 & 31.30 & 26.83 & 69.67 & 0.01787 \\
\hline $1620^{\star}$ & 32.46 & 27.43 & 67.32 & 0.01843 \\
\hline $1650^{\star 4}$ & 32.80 & 27.59 & 66.91 & 0.01863 \\
\hline $1680^{4+4+4}$ & 32.93 & 27.96 & 69.12 & 0.01935 \\
\hline $1680^{\rtimes}$ & 30.09 & 26.29 & 84.56 & 0.01794 \\
\hline 2300 & 32.99 & 29.05 & 73.82 & 0.02069 \\
\hline
\end{tabular}

* - $\mathrm{Q}_{0}=350 \mathrm{~kW} ;{ }^{\star-}-\mathrm{Q}_{0}=250 \mathrm{~kW} ;{ }^{\star}-\mathrm{Q}_{0}=35 \mathrm{~kW}$.

\section{Heat Transferred from the Surrounding Rock Massif into Mine Air}

Calculations of the amount of heat emitted by the rock mass have also been performed. For this purpose, zones of rock mass cooling have been set for the seven abovementioned states of the longwall face position. The 
enumerated zones have been set separately for 50-metre sections of the bottom road, for 30-metre sections of the extraction longwall and for 50-metre sections of the top road. The proceedings are similar as in the work (Knechtel, 2011). However, opposed to the data contained in work (Knechtel, 2011), the original temperature of rock is variable both along the roadway as well as along the longwall face and moreover, due to the installation of chillers in workings, the air temperature changes stepwise which affects the temperature changes of the surrounding rock mass. Hence, rock temperature isolines in the function of distance from the side wall are more irregular. In the work, graphs of rock mass cooling around the following have been presented: bottom road, longwall and top road for three states: maximum longwall face, for half of the longwall face and for the state in which the longwall is to be complete. Ventilation times of main gates are significant (from a few dozen to 360 days). Whereas the longwall ventilation time is very short (several hours). This affects the state of rock mass cooling. The temperature of rock mass in the vicinity of the longwall working at a distance of app. $1.5 \mathrm{~m}$ from the side wall has the original value. Whereas in the case of main gates, the original temperature of rock occurs a dozen metres from the side wall.

Examining the process of rock mass cooling, similarly to works (Knechtel, 2006, 2011), 50-metre sections of the working have been discussed. In the case of longwall workings, these were 30 -metre sections. It has been assumed that each such section is surrounded by concentric cylinders, where the axes of these cylinders are equal to the axis of the working. The radius of the internal cylinder is equal to the equivalent radius of the working $\mathrm{r}_{0}$, the radiuses of subsequent cylinders are about $1 \mathrm{~m}$ bigger one from another (in case of concentric cylinders the radiuses are $0.1 \mathrm{~m}$ bigger around the longwall working). Whereas, the radius of the external cylinder is equal to the equivalent radius of the workings, extended by the distance into the rock mass from the side wall to the place with the original temperature. Using the method described in work (Knechtel, 1998), the rock mass cooling areas around the following have been set: bottom road, longwall and top road. Calculations have been performed for the 7 given phases of the longwall face. The results have been shown graphically in figures 2, 3 and 4 (which concern the state for maximum longwall face) and in figures 5, 6 and 7 (which concern the period just before the end of the longwall movement). It must be mentioned, that for the maximum longwall face, the original temperature of rock surrounding the longwall working is the lowest (below $50^{\circ} \mathrm{C}$, and for the state before the end of the longwall movement is the highest (app. $53^{\circ} \mathrm{C}$ ).

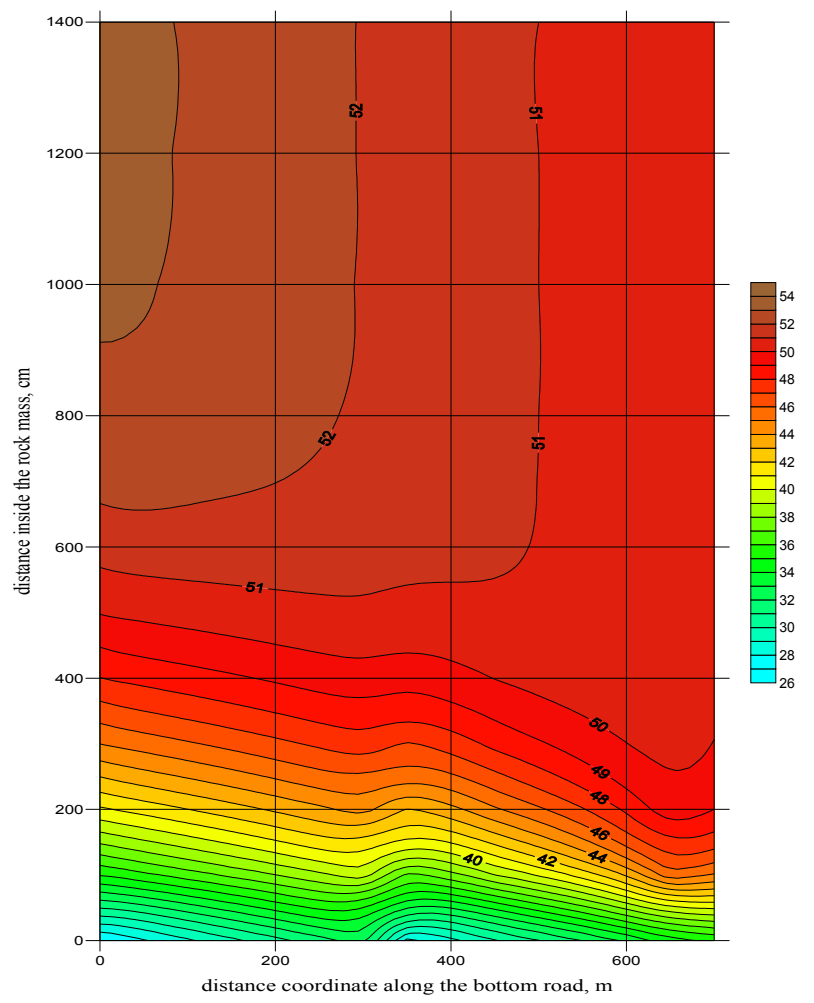

Figure 2. Cooling of rock mass around the bottom road for the maximum longwall face 


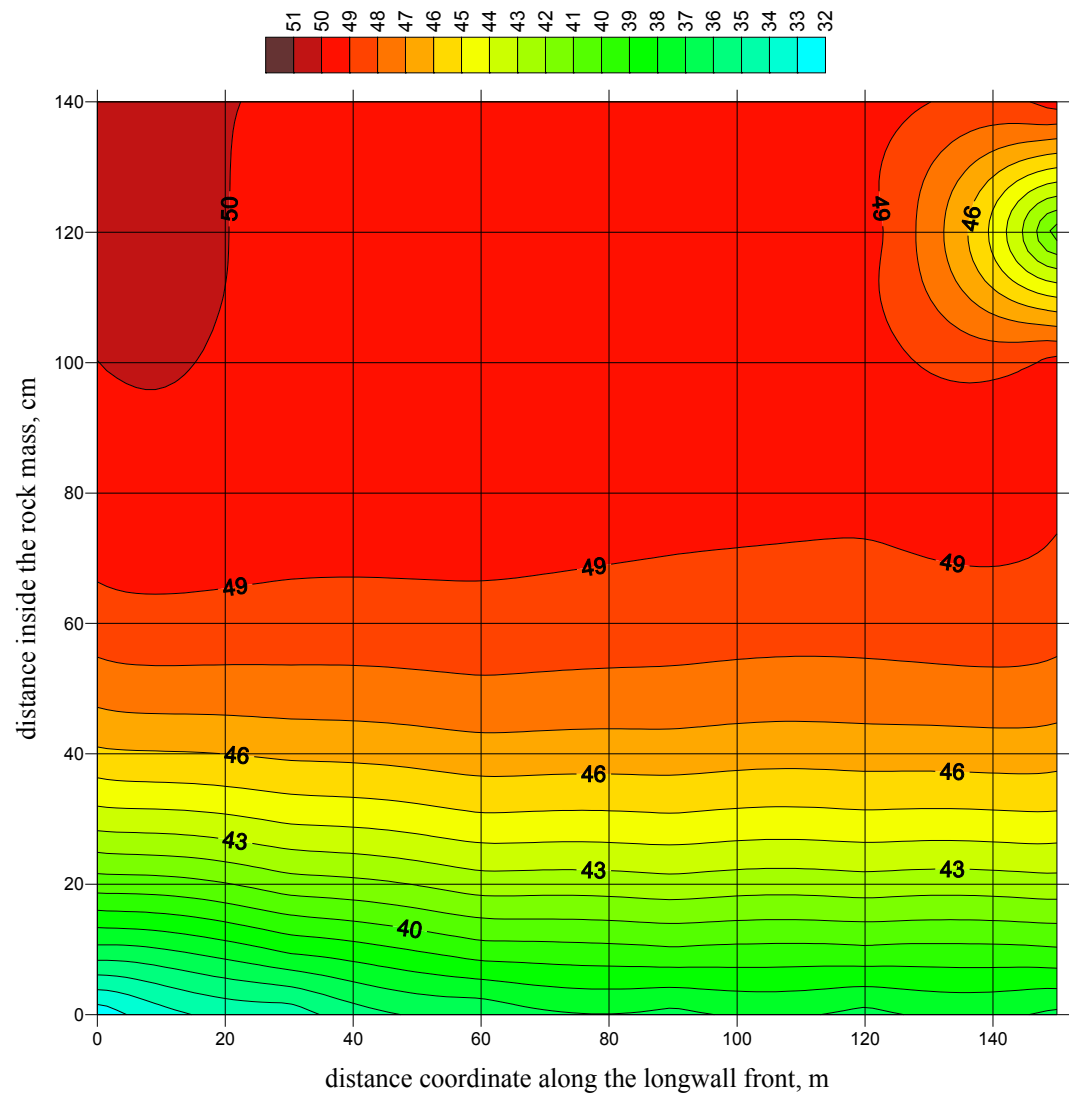

Figure 3. Cooling of rock mass around the longwall for its maximum face

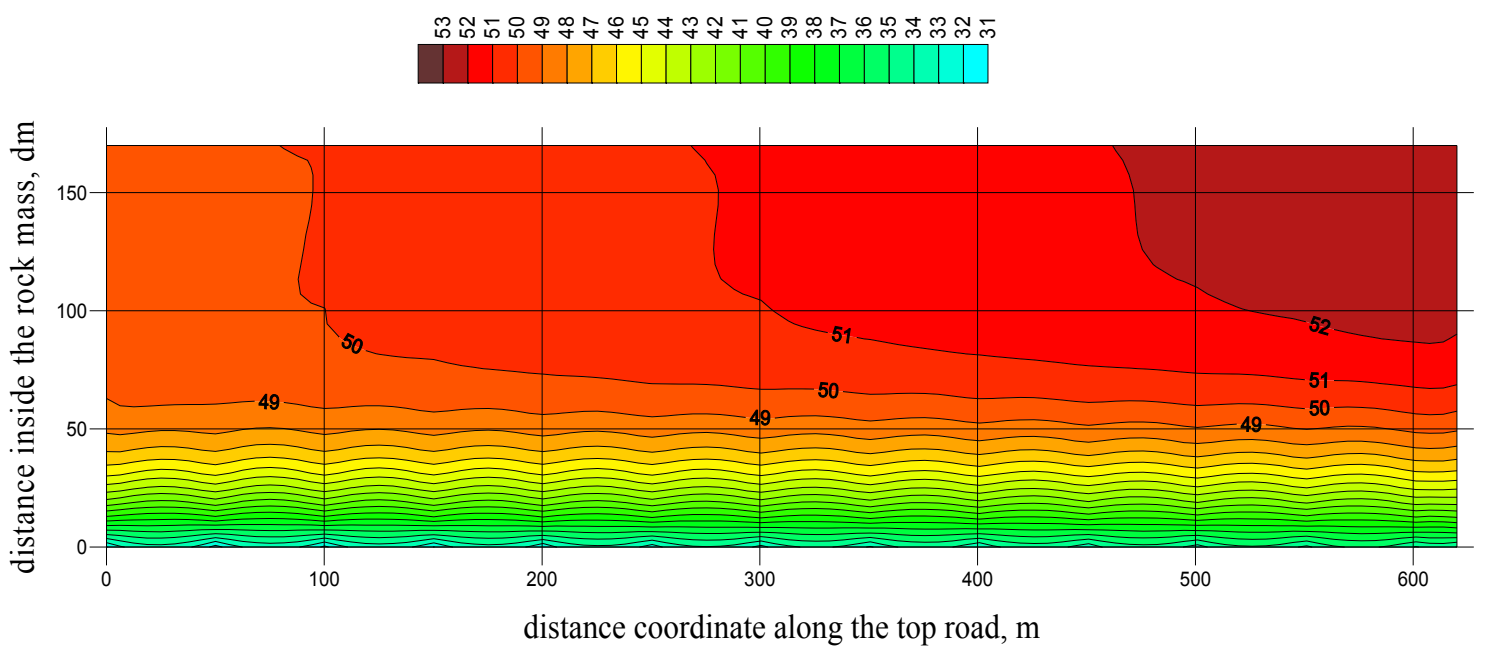

Figure 4. Cooling of rock mass around the top road for the maximum longwall face 


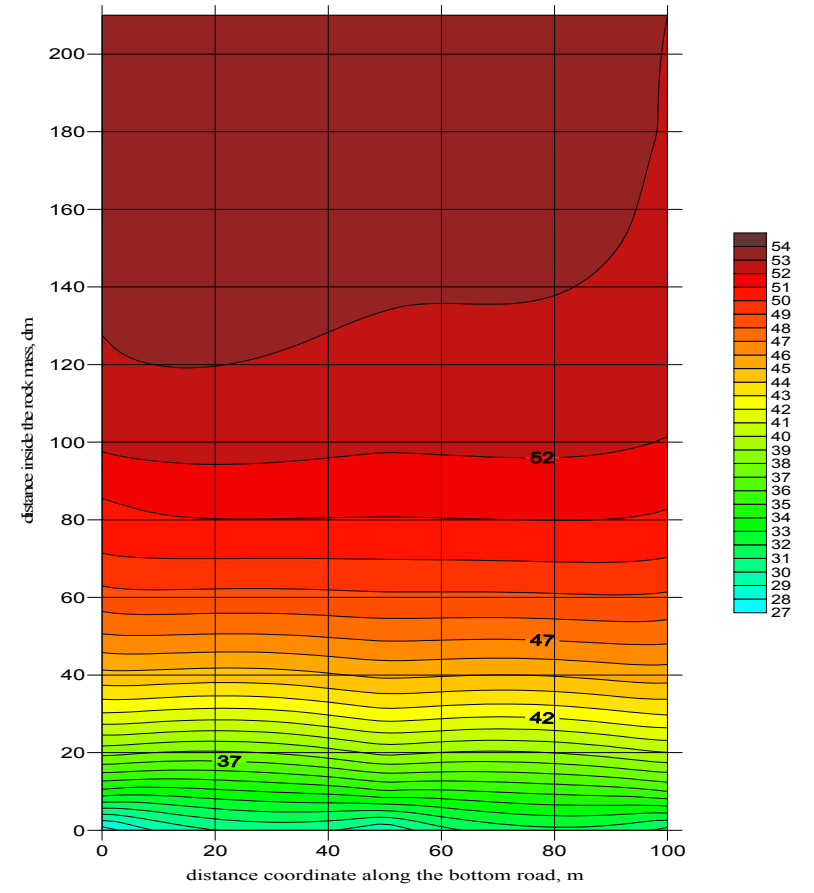

Figure 5. Cooling of rock mass around the bottom road for the final phase of the longwall face

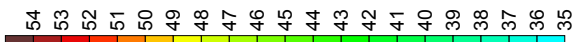

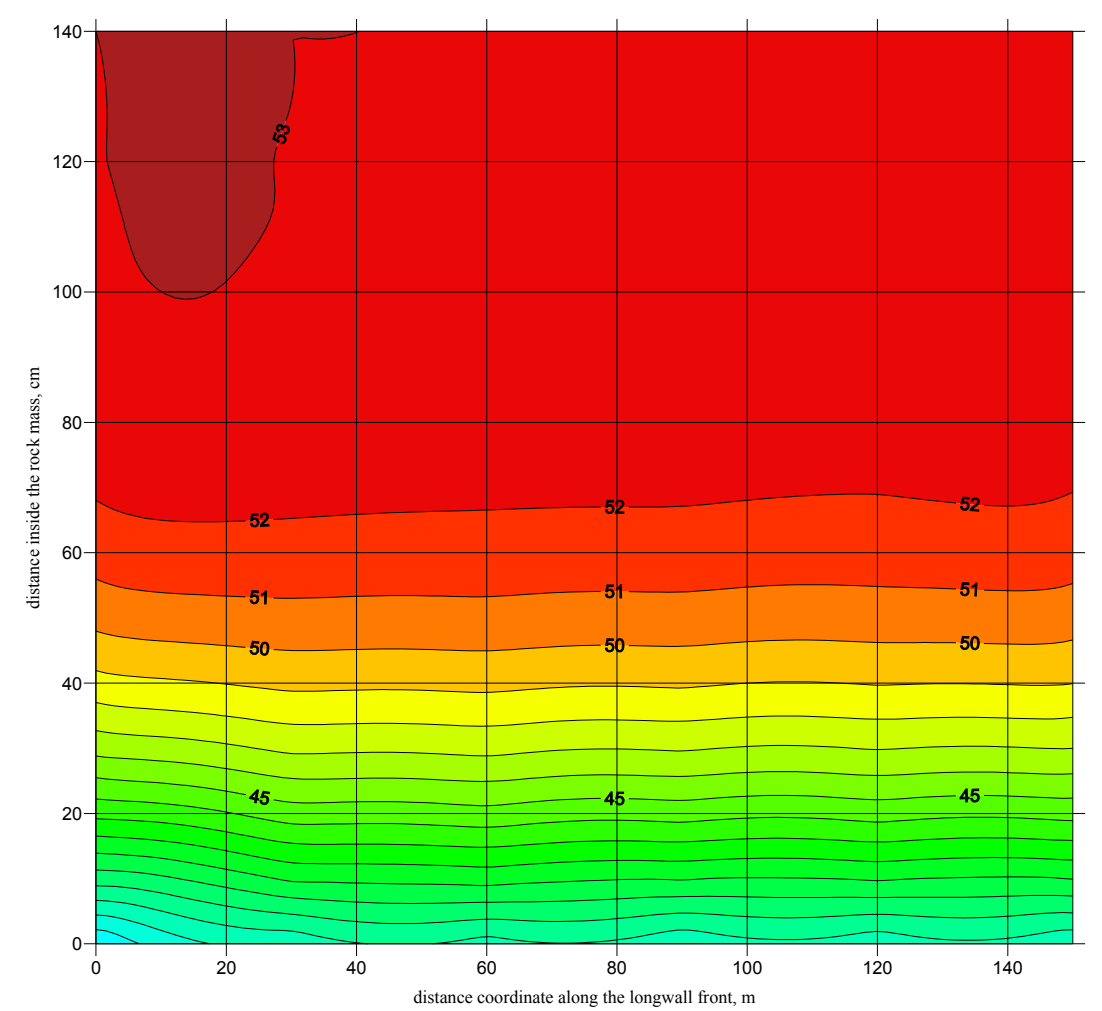

Figure 6. Cooling of rock mass around the longwall for the final phase of its face 


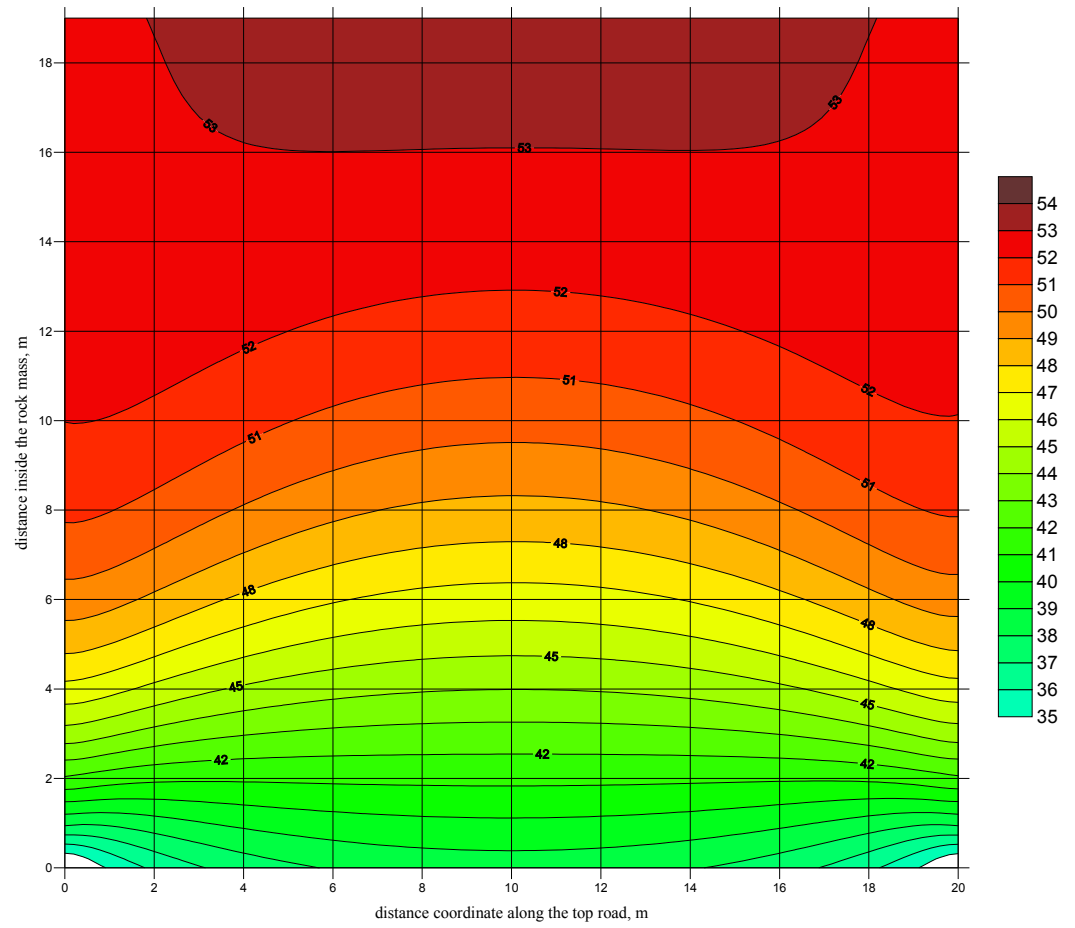

Figure 7. Cooling of rock mass around the top road for the final phase of the longwall face

In turn, the amounts of heat emitted by areas limited with cylinder surfaces have been calculated. The calculations assume that the coal density within the main gates is equal to $2000 \mathrm{~kg} / \mathrm{m}^{3}$, and within the longwall working to 1900 $\mathrm{kg} / \mathrm{m}^{3}$. Proper heat capacity within the main gates is equal to $920 \mathrm{~J} /(\mathrm{kgKK})$, and within the longwall working to 985 $\mathrm{J} /(\mathrm{kg} \mathrm{K})$. Multiplying the mass of the cylinder (from which a cylinder of a smaller radius has been cut off) by heat specific for coal and the original rock temperature difference and rock temperature after the ventilation period for the working, the amount of heat lost in the area limited by cylinder surfaces is obtained. By summing the amount of heat from each area, the amount of heat emitted during the discussed working section is obtained. Summing all sections, the amount of heat emitted by the rock mass after a specified period of time is obtained. The results of the calculations have been summarized in the following table.

Table 3. Amount of heat emitted by the rock mass in the individual phases of the longwall face

\begin{tabular}{|c|c|c|c|c|c|c|c|c|c|}
\hline \multirow[b]{2}{*}{ 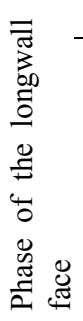 } & \multicolumn{3}{|c|}{ bottom road } & \multicolumn{3}{|c|}{ Longwall } & \multicolumn{3}{|c|}{ top road } \\
\hline & 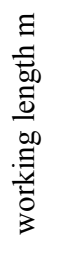 & 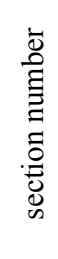 & $\begin{array}{l}\text { heat emitted } \\
\text { by rocks GJ }\end{array}$ & 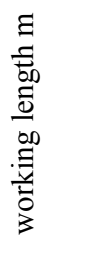 & 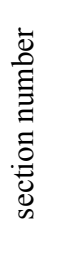 & $\begin{array}{l}\text { heat emitted } \\
\text { by rocks GJ }\end{array}$ & 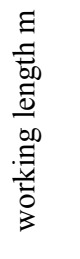 & 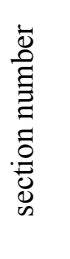 & $\begin{array}{l}\text { heat emitted } \\
\text { by rocks GJ }\end{array}$ \\
\hline \multirow[t]{8}{*}{1} & 2 & 3 & 4 & 5 & 6 & 7 & 8 & 9 & 10 \\
\hline & & 1 & 213.919 & & 1 & 97.439 & & 1 & 115.548 \\
\hline & & 2 & 196.691 & & 2 & 84.763 & & 2 & 123.583 \\
\hline & & 3 & 179.879 & 150 & 3 & 73.988 & & 3 & 130.313 \\
\hline & & 4 & 163.615 & & 4 & 70.506 & & 4 & 136.968 \\
\hline & & 5 & 147.933 & & 5 . & 70.327 & & 5 & 143.387 \\
\hline & & 6 & 132.625 & & & - & & 6 & 149.876 \\
\hline & & 7 & 118.073 & & & - & 620 & 7 & 155.899 \\
\hline \multirow[t]{3}{*}{1} & 700 & 8 & 136.004 & & & - & & 8 & 162.119 \\
\hline & & 9 & 119.965 & & & - & & 9 & 168.102 \\
\hline & & 10 & 100.956 & & & - & & 10 & 174.023 \\
\hline \multirow[t]{2}{*}{1} & 2 & 3 & 4 & 5 & 6 & 7 & 8 & 9 & 10 \\
\hline & & 11 & 85738 & & & - & & 11 & 180.024 \\
\hline
\end{tabular}




\begin{tabular}{|c|c|c|c|c|c|c|c|c|c|c|}
\hline & & 12 & 70.857 & & & & - & & 12 & 185.698 \\
\hline & & 13 & 55.836 & & & & - & & 13 & 75.536 \\
\hline & & 14 & 40.039 & & & & - & & & - \\
\hline & & & 1762.130 & & total & & 397.022 & & & 1901.077 \\
\hline & & 1 & 239.064 & & & 1 & 80.797 & & 1 & 142.334 \\
\hline & & 2 & 220.931 & & & 2 & 72.003 & & 2 & 148.955 \\
\hline & & 3 & 203.478 & 150 & & 3 & 70.126 & & 3 & 157.399 \\
\hline & & 4 & 186.515 & & & 4 & 72.799 & & 4 & 161.973 \\
\hline & & 5 & 170.237 & & & 5 & 75.125 & & 5 & 168.446 \\
\hline & & 6 & 154.526 & & & & - & & 6 & 174.643 \\
\hline \multirow[t]{11}{*}{2} & 600 & 7 & 139.309 & & & & - & 520 & 7 & 181.082 \\
\hline & & 8 & 163.982 & & & & - & & 8 & 187.129 \\
\hline & & 9 & 147.042 & & & & - & & 9 & 193.148 \\
\hline & & 10 & 130.610 & & & & - & & 10 & 199.370 \\
\hline & & 11 & 112.148 & & & & - & & 11 & 81.757 \\
\hline & & 12 & 99.947 & & & & - & & & - \\
\hline & & & 1967.787 & & total & & 370.851 & & & 1796.237 \\
\hline & & 1 & 254.392 & & & 1 & 83.143 & & 1 & 156.933 \\
\hline & & 2 & 236.216 & & & 2 & 74.553 & & 2 & 163.417 \\
\hline & & 3 & 218.559 & 150 & & 3 & 73.374 & & 3 & 169.735 \\
\hline & & 4 & 201.554 & & & 4 & 75.879 & & 4 & 175.782 \\
\hline \multirow[t]{7}{*}{3} & 500 & 5 & 185.114 & & & 5 & 75.494 & 420 & 5 & 181.967 \\
\hline & & 6 & 169.065 & & & & - & & 6 & 188.078 \\
\hline & & 7 & 153.870 & & & & - & & 7 & 194.178 \\
\hline & & 8 & 178.276 & & & & - & & 8 & 200.018 \\
\hline & & 9 & 160.374 & & & & - & & 9 & - \\
\hline & & 10 & 143.089 & & & & - & & & - \\
\hline & & & 1900.508 & & total & & 382.443 & & & 1511.480 \\
\hline \multirow[t]{4}{*}{1} & 2 & 3 & 4 & 5 & & 6 & 7 & 8 & 9 & 10 \\
\hline & & 1 & 281.114 & & & 1 & 95324 & & 1 & 179.386 \\
\hline & & 2 & 261.498 & & & 2 & 82.852 & & 2 & 185.629 \\
\hline & & 3 & 242.609 & 150 & & 3 & 77.204 & & 3 & 191.711 \\
\hline \multirow[t]{8}{*}{4} & 400 & 4 & 223.991 & & & 4 & 79.351 & 320 & 4 & 198.058 \\
\hline & & 5 & 206.140 & & & 5 & 81.056 & & 5 & 204.026 \\
\hline & & 6 & 188.980 & & & & - & & 6 & 210.178 \\
\hline & & 7 & 213.405 & & & & - & & 7 & 85.440 \\
\hline & & 8 & 188.741 & & & & - & & & - \\
\hline & & & 1806.478 & & total & & 415.787 & & & 1254.428 \\
\hline & & 1 & 298.449 & & & 1 & 104.611 & & 1 & 197.000 \\
\hline & & 2 & 274.691 & & & 2 & 91.753 & & 2 & 203.273 \\
\hline \multirow[t]{7}{*}{5} & 300 & 3 & 251.584 & 150 & & 3 & 79.978 & 220 & 3 & 209.603 \\
\hline & & 4 & 229.291 & & & 4 & 79.593 & & 4 & 215.651 \\
\hline & & 5 & 207.816 & & & 5 & 81.498 & & 5 & 87.689 \\
\hline & & 6 & 186.762 & & & & - & & & - \\
\hline & & & 1448.591 & & total & & 437.434 & & & 913.216 \\
\hline & & 1 & 317.462 & & & 1 & 88.418 & & 1 & 218.337 \\
\hline & & 2 & 293.196 & & & 2 & 82.266 & 120 & 2 & 224.736 \\
\hline \multirow[t]{7}{*}{6} & 200 & 3 & 269.408 & 150 & & 3 & 79.862 & & 3 & 91.436 \\
\hline & & 4 & 246.520 & & & 4 & 87.729 & & & - \\
\hline & & & - & & & 5 & 84.542 & & & - \\
\hline & & & 1126.586 & & total & & 422.818 & & & 534.508 \\
\hline & & 1 & 338.853 & & & 1 & 98.624 & 20 & 1 & 90.538 \\
\hline & 100 & 2 & 307.945 & & & 2 & 85.998 & & & - \\
\hline & & & - & 150 & & 3 & 83.352 & & & - \\
\hline \multirow[t]{3}{*}{7} & & & - & & & 4 & 85.850 & & & - \\
\hline & & & - & & & 5 & 85.062 & & & - \\
\hline & & & 646.798 & & total & & 438.886 & & & 90.538 \\
\hline
\end{tabular}

During extraction the longwall face passes through an area of very short ventilation time (4 hours), uncovering newer and newer surfaces. That is why one may sum the amounts of heat emitted by the rock mass in the individual phases of the longwall face. In result the value of $2865.241 \mathrm{GJ}$ is obtained. In the case of main gates the situation is 
different. The sections existing only in the phase of the maximum longwall face are ventilated the shortest. After the completion of the longwall face, the sections are liquidated, whereas the sections existing throughout the whole period of longwall extraction are ventilated the longest. In relation to the above, summing the heat emitted by rock mass in the bottom and top road is conducted in such a way that to the heat emitted in the last phase of the longwall face we add the heat emitted by the rock mass in the section where it emitted the heat in the last by one phase, next, we add the heat in the section from the previous phase and so on, until we reach the section existing only in the first phase of the longwall face. The amounts of heat obtained in this way are as follows: for the bottom road - 2570.883 GJ and for top road - 2149.669 GJ. In total, in the area of the longwall and the main gates, the rock mass loses $7585.793 \mathrm{GJ}$ of heat. This is several times less than the heat absorbed by chillers. It must however be remembered that chillers absorbed heat not only from the longwall and the main gate but also from the incline (located in rocks of the temperature of above $50^{\circ} \mathrm{C}$ ), and especially the heat from coal-winning and haulage devices in workings. The longwall operation lasted six months. The amount of heat which at that time was emitted by the rock mass into the area is much greater than the corresponding amount of heat, as referred to in the work (Knechtel, 2011). In work (Knechtel, 2011) a similar mining department is discussed, but the original temperature of rock is of about $8^{0} \mathrm{C}$ lower as well as the intensity of the area ventilation.

To make the extraction from deep coal seams (where the original temperature of rock amount to about $50^{\circ} \mathrm{C}$ ) possible, it is necessary to prepare significant expenditure for air-conditioning. This expenditure, however, may be partly returned. By applying classical air-conditioning at the underground of the mine, the temperature of hot water leaving the condenser within $45 \div 48^{\circ} \mathrm{C}$ (Luska \& Nawrat, 2008) may be obtained. Water of such temperature can be used on the surface. From work (Luska \& Nawrat, 2008), it appears that $77.5 \mathrm{~kg} / \mathrm{s}$ of cooling water flows through the water cooling unit with a power of $2 \mathrm{MW}$ (i.e. of the same power which is needed for the air-conditioning of the discussed area). This water could be used on the surface for powering the crystallizer of the absorption chiller. In this way, part of the expenditure on the air-conditioning would be returned.

\section{Summary}

Considerations on heat emitted during operation in hot rock mass have been conducted. A hot mining department in one of OKD mines has been chosen to be considered. The original temperature of the surrounding rocks is greater than $50^{\circ} \mathrm{C}$. The total power of the department's energy-mechanical devices (located in the incline, bottom road and in the longwall) exceeds $6 \mathrm{MW}$. Performed climate forecasts showed that in order to ensure the air temperature no higher than $33^{\circ} \mathrm{C}$ in a current of fresh air, chillers of cooling power of about $2 \mathrm{MW}$ should be developed. The results of the considerations on the heat stream coming from the hot rock mass show that about $30 \%$ of the installed refrigeration capacity is needed to transfer the rock mass heat. Hot water from cooling devices could be used to power the absorption crystallizer of the cooling device running on the surface. In the mine "Pniówek", "warm-water" chillers are powered by water of $85^{\circ} \mathrm{C}$ (Jakubów, 2006). The temperature of the water leaving the chiller's condenser at the underground of the mine is about $40^{\circ} \mathrm{C}$ lower. This water can however be mixed with water of a temperature of $125^{\circ} \mathrm{C}$, which powers the "warm-water" absorption chillers, being the second stage of cooling cold water. In works (Knechtel, 2006, 2011) it was proposed that hot water from condensers might be used on the surface for municipal purposes. In this case, however, a network of insulated pipelines distributing the water to users is necessary. Whereas the use of this water to power absorption crystallizers of cooling devices should contribute to reduce the cost of air-conditioning, which are borne anyway.

\section{References}

Batzel, S. (1952). Die Ermittlung thermischer Werte in Grubenbauen und ihre Verwendung für die mathematische Lösung klimatischer Probleme. Bergbau - Archiv H.3/4.

Benet, J. C., \& Jouanna, P. (1982). Phenomenological relation of phase change of water in porous medium: experimental verification and measurement of the phenomenological coefficient. Int. J. Heat MassTransfer, 25(11). http://dx.doi.org/10.1016/0017-9310(82)90154-5

Benet, J. C., \& Jouanna, P. (1983). Non equilibre thermodinamique dans les moieux poreux non satures avec changement de phase. Int. J. Heat Mass Transfer, 26(11). http://dx.doi.org/10.1016/S0017-9310(83)80077-5

Boldizsar, T. (1960). Ein numerisch - graphisches Verfahren zur Berechnung der Erwärmung von Grubenwettern, Bergbau - Archiv H.2.

Holek, S. (1990). The development of the potential of the movement of moisture and based on it methods of forecasting a microclimate of mining workings, Prace Głównego Instytutu Górnictwa, additional series, Katowice.

Jakubów, A., Tor, A., \& Wacławik, J. (2006). The absorption refrigerators in mining air conditioning, Proceedings 
of the $2^{\text {th }}$ School of Mine Ventilation, Zakopane.

Knechtel, J. (1998). The Influence of Thermal Insulation of Wall sof Workings on Air Temperature. Archives of Mining Science, 43(4), 517-533.

Knechtel, J. (1998). The investigation concerning the feasibility of utilization of thermal energy carried away by ventilating air to the surface, Zeszyty Naukowe Politechniki Śląskiej Seria: Górnictwo z.270, 257-264.

Knechtel, J. (2006). Remarks concerning the possibility of utilization of condensation heat from cooling devices, Proceedings of the $4^{\text {th }}$ School of Mine Ventilation, Kraków, 307-316.

Knechtel, J. (2006). Study results on the possibilities of utilizing heat contained in mine air. Bezpieczeństwo Pracy i Ochrona Środowiska w Górnictwie, 8(144), 9-23.

Knechtel, J. (2011). Considerations Concerning The Stream of Heat Transferred from Rock Mass into Mine Ventilation Air and The Utilization of this Heat by Means of Air Cooling Installations. Geo Science Engineering, LVII(2), 1-12.

Łuska, P., \& Nawrat, S. (2008). Air-conditioning of underground mines. Cooling systems, Uczelniane Wydawnictwa Naukowo Dydaktyczne AGH, Kraków.

Marzilger, B., \& Wagener, B. (1972). Eine numerische Lösung zur Berechnung des wärmetechnischen Altersbeiwertes mit Fehlerabschätzung, Glückauf -Forschungshefte H.4.

Nottrot, R., \& Sadèe, C. (1966). Abkühlung homogenen isotropen Gesteins um eine zylindrische Strecke durch Wetter von konstanter Temperatur. Glückauf -Forschungshefte H.4.

Voß, J. (1965). Ein Verfahren zum Bestimmen der Wärme- und Wasserdampfabgabe von Förderkohle und von Versatzbergen in Abbaustrecken und Streben Glückauf - Forschungshefte H.3.

Voß, J. (1969). Ein neues Verfahren zur Klimavorausberechnung in Steinkohlenbergwerken Glückauf $\div$ Forschungshefte H. 6.

\section{Copyrights}

Copyright for this article is retained by the author(s), with first publication rights granted to the journal.

This is an open-access article distributed under the terms and conditions of the Creative Commons Attribution license (http://creativecommons.org/licenses/by/3.0/). 